\title{
Astringency in 'Giombo' persimmon and its relationship with the harvest time
}

\author{
Magda Andréia Tessmer ${ }^{*}$, Beatriz Appezzato-da-Glórial', Ricardo Alfredo Kluge ${ }^{1}$
}

10.1590/0034-737X201663050008

\begin{abstract}
'Giombo' is one of most cultivated persimmon cultivars in Brazil. It is a late-harvest cultivar and requires treatment for astringency removal. The aim of this study was to evaluate the efficiency of ethanol and the effect of harvest time on reducing astringency, physicochemical and anatomical characteristics of 'Giombo' persimmon. Two experiments were carried out, one in each growing season, with five treatments corresponding to exposure to $1.70 \mathrm{~mL} \mathrm{~kg}^{-1}$ ethanol for 0,12 , 24, 36 and 48 hours. At the end of the growing season (2011) the fruits achieved the astringency index and levels of soluble tannins suitable for consumption in 24 hours, and at the beginning of the growing season (2012) in 36 hours, indicating that the efficiency of the treatment is related to harvest time and ethanol exposure time. Astringency removal with ethanol affects the cell structure with accumulation of substances inside the cells and in intercellular spaces, resulting in the degradation of the parenchyma cell wall. To avoid such damage and maintain fruit quality, it is recommended the combination of low ethanol doses with less ethanol exposure time.
\end{abstract}

Key words: acetaldehyde; astringency; ethanol; Diospyros kaki L.; harvest.

\section{RESUMO}

\section{Destanização de caquis ‘Giombo’ e sua relação com a época de colheita}

O caquizeiro 'Giombo' é uma das cultivares mais produzidas no Brasil, caracterizando-se por apresentar colheita tardia e necessidade de tratamento dos frutos para remoção da adstringência. O objetivo deste estudo foi avaliar a eficiência do etanol e o efeito da época de colheita sobre a redução da adstringência e as características físico-químicas e anatômicas em caquis 'Giombo'. Foram realizados dois experimentos, um em cada época de colheita, com cinco tratamentos correspondentes ao tempo de exposição ao etanol $1,70 \mathrm{~mL} \mathrm{~kg}^{-1}: 0,12,24,36$ e 48 horas. No fim de safra (2011) os frutos obtiveram índice de adstringência e teores de taninos solúveis adequados para consumo em 24 horas e, no início de safra (2012), em 36 horas, o que revela que a eficiência dos tratamentos está relacionada à época de colheita e ao tempo de exposição dos frutos ao etanol. A remoção da adstringência com etanol afeta a estrutura celular, com acúmulo de substâncias no interior das células e nos espaços intercelulares, resultante da degradação da parede celular do parênquima. Para evitar estes danos e manter a qualidade dos frutos, deve-se combinar baixas doses de etanol com menor tempo de exposição.

Palavras-chave: acetaldeído; adstringência; colheita; Diospyros kaki L.; etanol.

Submitted on September 30th, 2014 and accepted on May 24 $4^{\text {th }}, 2016$.

${ }^{1}$ Universidade de São Paulo, Escola Superior de Agricultura "Luiz de Queiroz", Departamento de Ciências Biológicas, Piracicaba, São Paulo, Brasil. magdatessmer@yahoo.com.br; bagloria@usp.br; rakluge@usp.br

*Corresponding author: magdatessmer@yahoo.com.br 


\section{INTRODUCTION}

Brazil ranks as the fourth largest persimmon producer worldwide. In the 2012 crop, the domestic production achieved 158,241 tons in a planted area of 8,170 hectares (FAOSTAT, 2016). 'Giombo' is one of the most planted cultivars and is classified into the group of astringent and pollination variant (PVA), which are edible only after removal of astringency.

The astringency in persimmon is caused by tannins accumulated in the vacuoles of tannin cells present in the fruit pericarp (Tessmer et al., 2014). Tannins are classified into two groups, according to their chemical structure: hydrolysable or soluble tannins mainly formed from gallic acid (gallotannins) and hexahydrodiphenic acid (ellagitannins) esterified to a polyol, usually D-glucose and condensed tannins or proanthocyanidins consisting of flava-3-ols units (catechin), or flavan 3,4-diols (leucoanthocianyns) (Handique \& Baruah, 2002).

Astringency reduction by artificial process is due to polymerization reactions of the C-8 or C- 6 of proanthocyanidins with acetaldehyde, which is produced by inducing anaerobic respiration in the presence of high $\mathrm{CO}_{2}$ concentrations (Besada et al. 2012) or the reverse reaction of ethanol-acetaldehyde production (Taira et al. 1989).

In Brazil, farmers have used ethanol for persimmon deastringency because of its low cost. Studies on ethanol rates and ethanol exposure times (Edagi et al., 2009a; Antoniolli et al., 2000), as well as temperature (Monteiro et al., 2012) have been performed on 'Giombo' persimmon.

Maturation stage (Edagi et al., 2009b; Salvador et al., 2007; Ramin \& Tabatabaie, 2003; Taira et al, 1990) and harvest season (Vitti et al., 2009) may influence deastringency of different persimmon cultivars. According to Vitti (2009), 'Rama Forte' persimmon harvested in mid and late growing season has more characteristics of advanced ripening such as skin color changes, loss of firmness and reduced astringency compared with the beginning of the growing season. Astringency can also be influenced by environmental factors such as temperature throughout the growing season. However, the relationship of harvest season and de-astringency has not been studied in 'Giombo' persimmon.

In this context, the objective of this study was to evaluate the efficiency of ethanol and the effect of harvest time on reducing astringency and the physicochemical and anatomical characteristics of 'Giombo' persimmon.

\section{MATERIALAND METHODS \\ Plant material and treatments}

Fruits of cultivar Giombo were picked in a commercial orchard located in Mogi das Cruzes-SP (23 $31^{\prime}$ S and 46 $11^{\prime}$
W) at $742 \mathrm{~m}$ altitude. The first experiment was conducted in July 2011 (end of growing season) and the second in April 2012 (beginning of growing season). After harvest, the fruits were taken to the Postharvest Physiology and Biochemistry Laboratory, ESALQ/USP, subjected to rigorous selection for size, absence of mechanical damage and orange color at the end of growing season (2011) and orange-yellow at the beginning of growing season (2012). The difference in skin color is due to pigment accumulation, which gives a deeper orange color from mid to the end of the growing season.

Both experiments were carried out with $1.70 \mathrm{~mL} \mathrm{~kg}^{-1}$ ethanol and 5 exposure times: T0: fruit characterization; T1: 12 hour exposure; T2: 24 hour exposure; T3: 36 hour exposure and T4: 48 hour exposure. The ethanol rate was based on preliminary studies showing that it helped to keep the fruit quality, especially pulp firmness (Miller $e t$ al., 2012; Edagi et al., 2009a).

Ethanol was applied in Petri dishes placed at the bottom of $0.50 \times 0.80 \times 0.47 \mathrm{~m}$ boxes to avoid direct contact with the fruits. Then, the boxes were tightly sealed to promote gas mixing and kept at $22 \pm 1{ }^{\circ} \mathrm{C}$ during the treatment.

After the different exposure times, the fruits were kept at $22 \pm 1{ }^{\circ} \mathrm{C}$ for 5 days at the end of the growing season, in 2011, and for three days at the beginning of the growing season, in 2012, to induce the de-astringency process. The evaluations were performed after harvest (T0), at the end of each exposure time + time of tannin polymerization (days). Structural analysis and astringency index were carried out, as well as portions of the samples were frozen for quantification of total and soluble tannins, ethanol and acetaldehyde.

\section{Light microscopy (LM)}

Fruits of the end of growing season (2011) had portions of the equatorial region removed, fixed in Karnovsky's solution (Karnovsky, 1965), subjected to vacuum to remove air bubbles, dehydrated in an ethanol series up to $100 \%$, and embedded in resin to make the blocks. The blocks were cut in 5-6 $\mu \mathrm{m}$ thick sections on a rotary microtome. The sections were stained with toluidine blue (Sakai, 1973) for usual analysis and mounted on slides with synthetic resin Entellan ${ }^{\circledR}$. This technique showed structural changes, but it was not possible to differentiate the cells containing soluble and insoluble tannins. In fruits of the beginning of the growing season (2012), fresh tissue sections of the equatorial region were cut with a stainless blade. The sections were placed on histological slides, stained with $10 \%$ hydrochloric vanillin for tannin reaction, and covered with cover slip. Digital images were taken using a Leica DM LB trinocular microscope coupled to a Leica DC $300 \mathrm{~F}$ video camera and captured on a computer to make the figures. 


\section{Astringency index}

Astringency index was determined using the method by Field-Dall'Orto et al. (1996), in which filter paper previously soaked in ferric chloride $\left(\mathrm{FeCl}_{3}\right)$ solution at $5 \%$ is applied to one the faces of the fruit cut in the equatorial region. Tannin, in the soluble form, reacts with ferric chloride and turns dark. The impressions were evaluated using the rating scale: $1=$ not astringency; $2=$ slightly astringency; $3=$ moderately astringency; $4=$ astringency; $5=$ very astringency.

\section{Total and soluble tannin contents}

Contents of total and soluble tannins were determined by spectrophotometry using the Follin-Ciocalteu reagent (50\%), according to Taira (1995). One gram (1 g) of ground pulp was used to prepare a final volume of $100 \mathrm{~mL}$ of extract, from which a $1 \mathrm{~mL}$ aliquot was taken. This aliquot was added with Follin-Ciocalteu reagent (50\%), plus $1 \mathrm{~mL}$ of supersaturated sodium carbonate solution, and $7.5 \mathrm{~mL}$ of distilled water. The reading was performed in a BiochromLibra S22 spectrophotometer with absorbance at $725 \mathrm{~nm}$. The results were expressed as $\mathrm{g}$ of tannin per $100 \mathrm{~g}$ of fresh pulp (fp).

\section{Acetaldehyde and ethanol}

Determination of acetaldehyde and ethanol concentrations was according to the methodology by Davis \& Chace (1969): $1 \mathrm{~g}$ of the ground pulp was sealed in $40 \mathrm{~mL}$ glass bottles and kept in a freezer at $-26{ }^{\circ} \mathrm{C}$ until analysis. The bottles were incubated in a water bath for 30 minutes at $50{ }^{\circ} \mathrm{C}$ (standards and samples), and $1 \mathrm{~mL}$ of the air in the bottles was collected with a syringe and injected into a Thermo Quest Trace GC 2000 Finnigan gas chromatograph with flame ionization detector (FID) and a Porapak-N column. Chromatograph settings were: oven at $140{ }^{\circ} \mathrm{C}$ for 8 minutes, then raised to $180^{\circ} \mathrm{C}$ by $20^{\circ} \mathrm{C} / \mathrm{min}$, held for $2 \mathrm{~min}$ for cleaning up the column; injector $150^{\circ} \mathrm{C}$; detector $180^{\circ} \mathrm{C}$; pressure $190 \mathrm{kPa}$ (constant) and $\mathrm{N}_{2}$ flow at $70 \mathrm{~mL} / \mathrm{min}$. The results were expressed as $\mu \mathrm{g}$ of ethanol and acetaldehyde per $\mathrm{g}^{-1}$ fresh pulp (fp).

\section{Experimental design and statistical analysis}

The experiments were arranged in a $2 \times 5$ factorial completely randomized design with 3 repetitions of 4 fruits per treatment. Data were analyzed for normality and subjected to analysis of variance (ANOVA), polynomial regression $(P<0.05)$ and 5\% Tukey test for comparison of treatment means between growing seasons. Analyses were performed using the software SISVAR (Ferreira, 2000).

\section{RESULTS AND DISCUSSION}

The effect of the interaction harvesting time and deastringency time was significant $(P<0.01)$ for the astringency index in astringency persimmon, which was represented by the polynomial regression curve (Figure 1). There was reduction in the astringency index after the de-astringency treatments in all ethanol exposure times.

Fruits of the end of growing season (2011) showed the astringency index score of 1.4 for 24 hours of exposure to ethanol, while the fruits of the beginning of the growing seasons (2012) showed the astringency index more reduced after 36 hours of exposure, also with score of 1.4, proper for consumption (Figure 1). Reduction of astringency in the shorter time in the fruits of the end of growing season (2011) may be related to the progress of ripening, characterized by the orange color at the end of the growing season.

Vitti (2009) found that persimmons 'Rama Forte' harvested in the mid and late growing season were less astringent than the fruits harvested at the beginning of the season; which is attributed to the efficiency of the deastringency process and the progress of ripening.

The reduction in the astringency index is due to polymerization of soluble tannins after the treatments with ethanol (Sugiura \& Tomana, 1983). Figure 2A shows the significant reduction $(P<0.01)$ in polymerization of soluble tannins with different ethanol exposure times.

Soon after the harvest, the contents of total and soluble tannins in astringency persimmon at the end and beginning of the growing season were similar (Figure 2A-B). Soluble tannin concentrations were reduced in all exposure times, with significantly lower values in fruits of the end of season (2011) than fruits of the beginning of the season (2012), except for the exposure time of 48 hours. For fruits of the end of season (2011), the most effective time for reduction

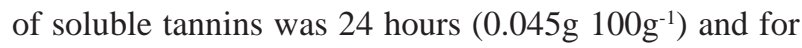
fruits of the beginning of the season (2012) was 36 hours $\left(0.169 \mathrm{~g} \mathrm{100g}^{-1}\right)$.

Edagi et al. (2009b) obtained persimmons suitable for consumption by applying low ethanol doses during the de-astringency process. These results also corroborate Yamada et al. (2002) and Antoniolli et al. (2000), who reported that de-astringency treatments were effective when reduced soluble tannins to levels near or below $0.10 \%$ and astringency index between 1.0 and 2.0.

Total tannins also decreased in comparison with the levels found prior to the exposure to ethanol, reaching the lowest values in treatments with the greatest reduction in soluble tannins (Figure 2B). Comparison of fruits harvested at the end with fruits harvested at the beginning of the season showed that the total tannin concentrations remained higher in fruits of the end of the season (2011), while fruits of the beginning of the season (2012) had the total tannin reduced to values close to soluble tannins (Figure 2A-B). Vitti (2009) also found reduction in total tannins after de-astringency of persimmons cultivar Rama 
Forte, but without significant differences in the concentrations of fruits harvested at the beginning, middle and end of the growing season.

The differences of optimum time for de-astringency of fruits at the beginning and end of the growing season may be related to the progress of ripening, which usually occurs in fruits of the end of the season. According to Salvador $e t$ al. (2007), the physiological stage of ripeness can be an important factor when it comes to assess the efficacy of the de-astringency method. The same authors found a reduction of soluble tannins in the astringent cultivar Rojo Brillante with the progress of ripening.

The analysis by light microscopy, resin-embedded samples from end-of-season fruits (2011) did not allow us to differentiate soluble from insoluble tannins (Figure 3A-B). However, they provided insight into the mesocarp structure of fruits after harvest, the parenchymal and tannin cells were shown intact (Figure 3A). In de-astringent fruits, substances

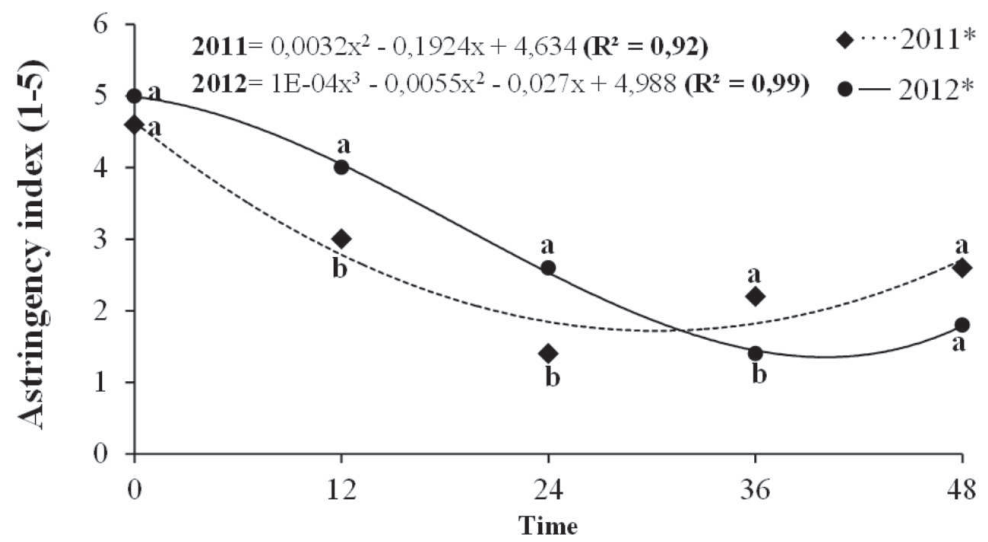

Figure 1: Astringency index of 'Giombo' persimmon with astringency removal by ethanol for $0,12,24,36$ and $48+5$ days at the end of the growing season (2011) and +3 days at the beginning of the season (2012), kept at $22 \pm 1{ }^{\circ} \mathrm{C}$. Same letters are not significantly different between harvest times by the Tukey test $(P<0.05)$. Significance of polynomial regression: $* P<0.01$.
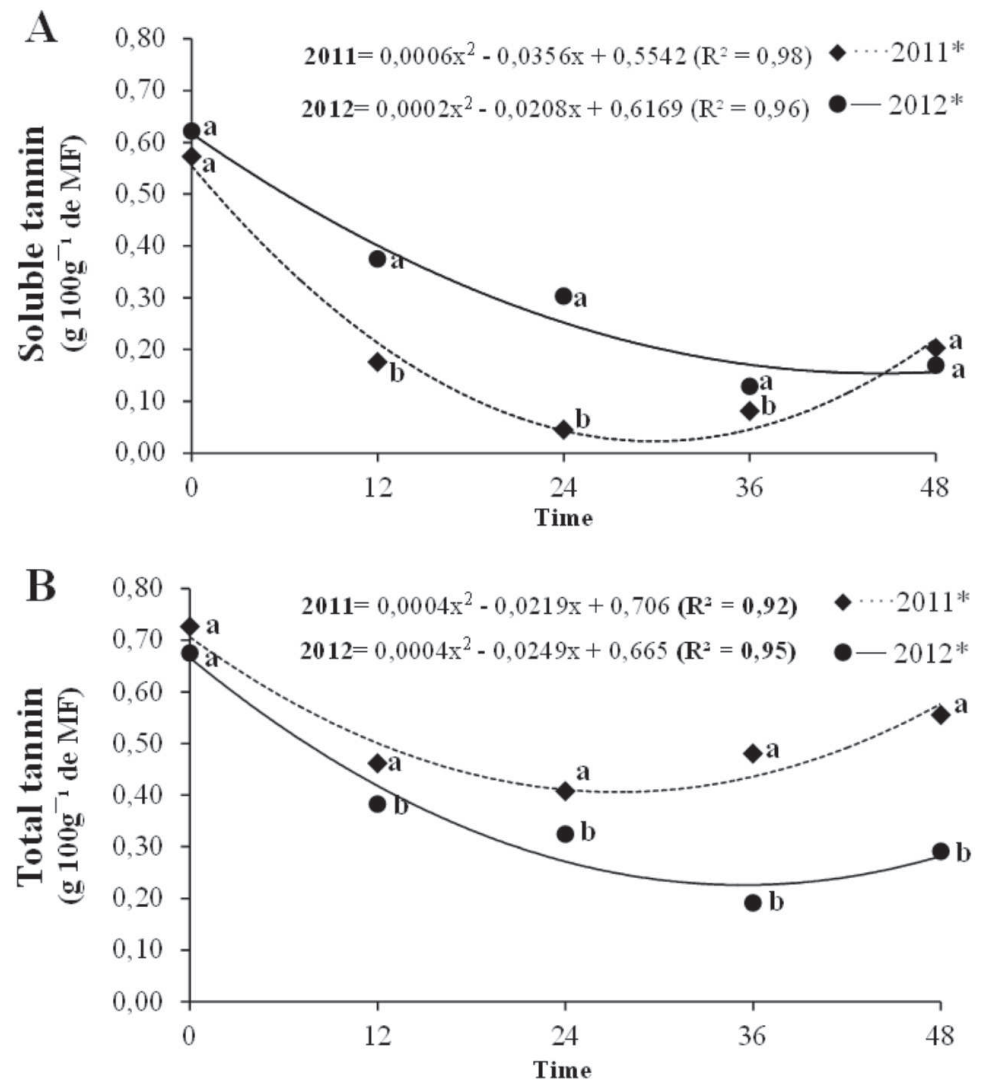

Figure 2: Soluble Tannins (A) and Total soluble (B) of 'Giombo' persimmon with astringency removal by ethanol for 12, 24, 36 and $48+5$ days at the end of growing season $(2011)+3$ days at the beginning of the season $(2012)$, kept at $22 \pm 1{ }^{\circ} \mathrm{C}$. Same letters are not significantly different between harvest times by the Tukey test $(P<0.05)$ in the treatments between the growing seasons. Significance of polynomial regression: $* P<0.01$. 
are observed accumulated inside of the cell and in intercellular spaces of the parenchyma cells, being more evident in fruits treated with 24 hours of ethanol exposure and greater reduction of soluble tannins (Figure 3B).

Salvador et al. (2007) discussed that during the process of deastringency with $\mathrm{CO}_{2}$, the insolubilization of tannins generates a mechanical effect of cell wall degradation in tannin cells. Similar damage may explain the structural changes described in deastringency of fruits with ethanol.

Fruits of the beginning of the season (2012) had a positive reaction of hydrochloric vanillin with the tannins in fresh mesocarp sections. When soluble, tannins extruded from inside the vacuole of the tannin cell and remained dispersed over the section with intense red staining (Figure $3 \mathrm{C})$. The test with vanillin also confirmed more insolubilized tannins in 36 hours of exposure to ethanol, since the tannin content of the vacuole is limited to the cells (Figure 3D). Intermediate stages of tannin insolubility are in the other treatments. Vazquez-Gutierrez et al. (2011) also reported that tannins are restricted to the vacuole of the cells, indicating their polymerization by formation of precipitates in persimmon.

Tannin polymerization is the due to the increase in the activity of the enzyme alcohol dehydrogenase, which promotes the reverse reaction turning ethanol into acetaldehyde and making them non-astringent (Pesis, 2005; Haslam, 1996). Pesis (2005) also reported that the natural accumulation of acetaldehyde is caused by fruit ripening, along with the increase in ethylene production, one of the compounds responsible for aroma formation.

The increase in the production of ethanol and acetaldehyde in the different de-astringency times was significant $(P<0.01)$ in the two growing seasons (Figure $4 \mathrm{~A}-\mathrm{B})$. Endogenous production of ethanol and acetaldehyde had similar values in fruits after harvest (T0), at the end (2011) and at the beginning of the growing season (2012).
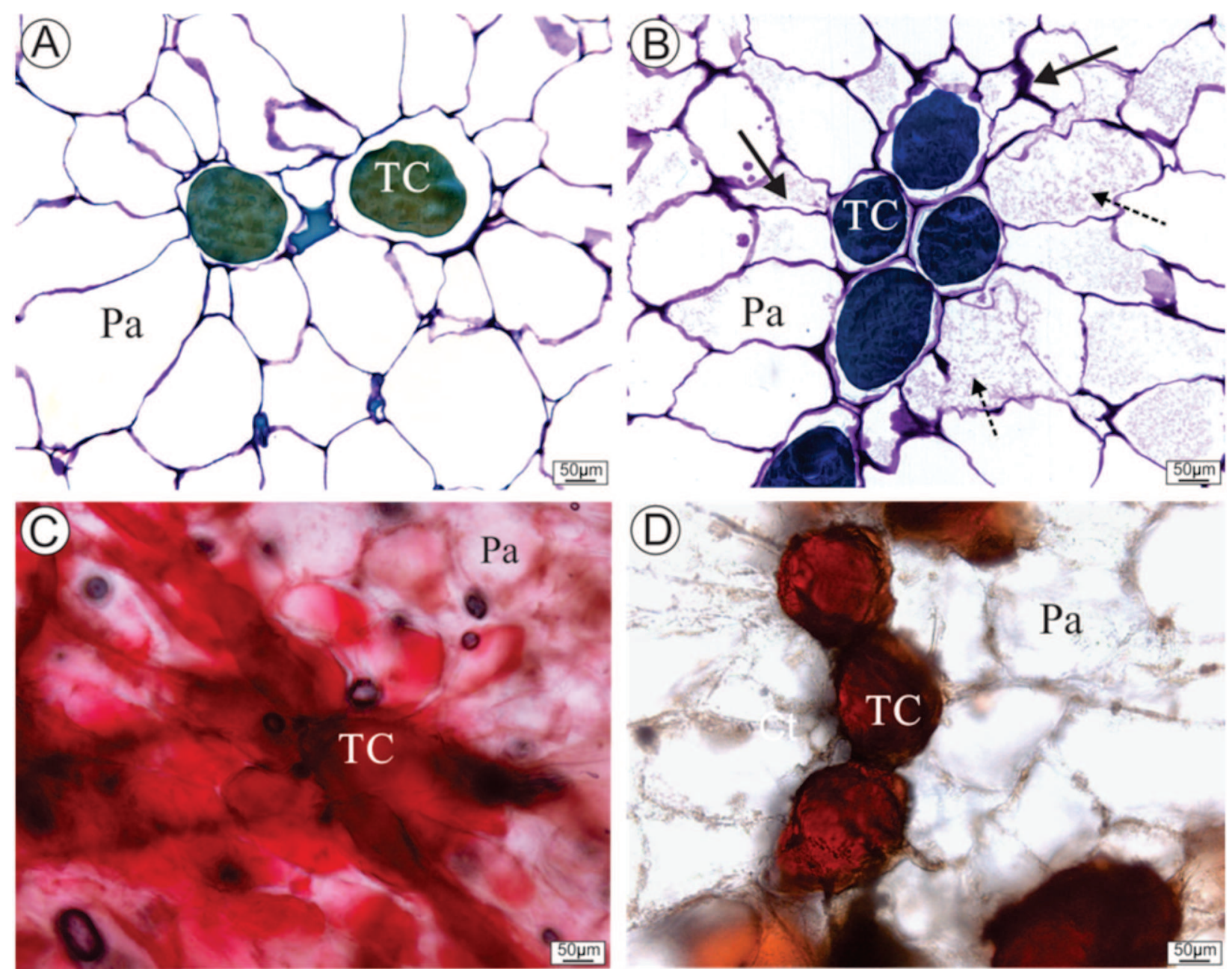

Figure 3: Cross sections of the 'Giombo' persimmon pericarp at the end of the growing season (2011) (A-B) and fresh sections at the beginning of the season (2012) (C, D). A. freshly picked fruits without astringency removal (T0). B. Fruits subjected to 24 hours exposure to ethanol. Pectic substances inside the parenchymal cells (dashed arrows) and accumulation of content in the intercellular spaces (lined arrows). C. Soluble tannins dispersed in the parenchyma of freshly picked fruits (T0). D. Insolubilized tannins restricted to the cell vacuole in fruits subjected to 36 hours exposure to ethanol. $\mathrm{CT}=$ Tannin Cell, $\mathrm{Pa}=\mathrm{Parenchyma}$ 
Comparing the two harvesting times, there was an increased production of ethanol after 24 hours of treatment in fruits harvested at the end of the growing season (2011) $\left(0.08176 \mu \mathrm{g} \mathrm{g}^{-1}\right)$ and in 36 hours at the beginning of the growing season (2012) $\left(0.11798 \mu \mathrm{g} \mathrm{g}^{-1}\right)$. Production of acetaldehyde was highest after 24 hours of exposure in fruits of the end of the growing season (2011) $\left(0.007 \mu \mathrm{g} \mathrm{g}^{-1}\right)$ and after 32 hours in fruits of the beginning of the growing season (2012) $\left(0.006574 \mu \mathrm{g} \mathrm{g}^{-1}\right)$ (Figure 4A-B). Treatments with the highest concentrations of these gases corroborate with the most effective treatments in the reduction of soluble tannins and the astringent index.

Adequate production of ethanol and acetaldehyde is important for fruit quality. High concentrations of acetaldehyde are toxic to plant cells (Pesis, 2005) as they can affect the cell structure and change the fruit flavor. Change in the mesocarp structure was observed in the anatomical study (Figure 3B), showing degraded content in the intercellular spaces and pectins within cells, and therefore, low-dose ethanol combined to shorter exposure time to reduce astringency is essential for fruit quality.
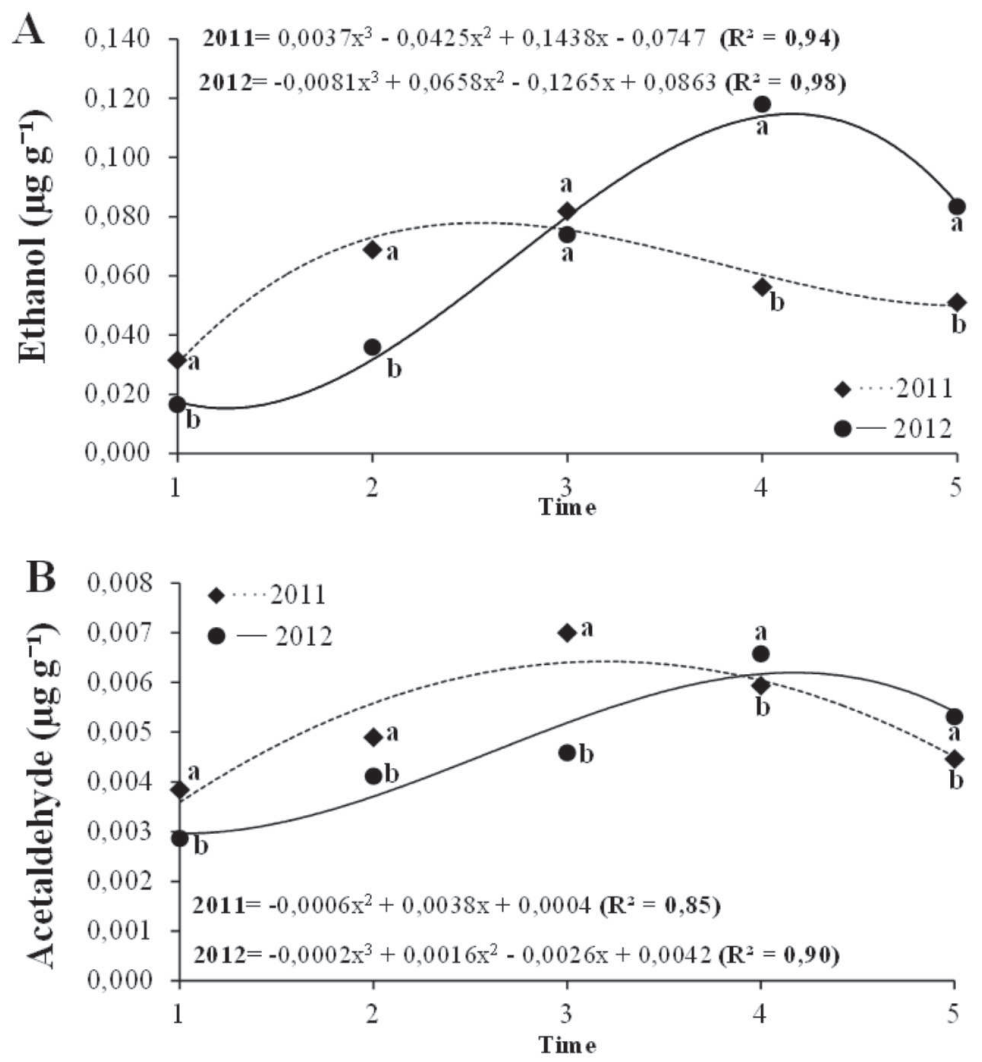

Figure 4: Ethanol and acetaldehyde concentrations in 'Giombo' persimmon with astringency removal by ethanol for 0, 12, 24, 36 and $48+5$ days pericarp at the end of the growing season (2011) +3 days pericarp at the beginning of the growing season (2012), kept at $22 \pm 1{ }^{\circ} \mathrm{C}$. Same letters are not significantly different between harvest times by the Tukey test $(P<0.05)$ in the treatments between the growing seasons. Significance of polynomial regression: $* P<0.01$.

\section{CONCLUSIONS}

The efficiency in astringency reduction is related to the growing season and the exposure time of fruits to ethanol.

In the harvest at the end of the growing season, the fruits showed astringency index and levels of soluble tannins suitable for consumption when exposed to ethanol for 24 hours.

In the harvest at the beginning of the growing season, the fruits showed astringency index and levels of soluble tannins suitable for consumption when exposed to ethanol for 36 hours.
Removal of astringency with ethanol affects cell structure with accumulation of substances inside the cells and in the intercellular space, resulting in degradation of the cell wall of the parenchyma tissue. To avoid such damage and preserve fruit quality, it is recommended to combine low doses of ethanol with shorter exposure time.

\section{ACKNOWLEDGEMENTS}

The authors thank the São Paulo Research Foundation (FAPESP) for the financial support to this research (Process 2010/16392-7) and the persimmon producers in Mogi das Cruzes, SP, Brazil, who kindly provided the fruits for the study. 


\section{REFERENCES}

Antoniolli LR, Castro PRC, Kluge RA \& Scarpare Filho JA (2000) Remoção da adstringência de frutos de caqui 'Giombo' sob diferentes períodos de exposição ao vapor de álcool etílico. Pesquisa Agropecuária Brasileira, 35:2083-2091.

Besada C, Sanchez G, Salvador A \& Granell A (2012) Volatile compounds associated to the loss of astringency in persimmon fruit revealed by untargeted GC-MS analysis. Metabolomics, 9:157-172.

Campo-Dall'Orto FA, Ojima M, Barbosa W \& Zullo MAT (1996) Novo processo de avaliação da adstringência dos frutos no melhoramento do caquizeiro. Bragantia, 55:237-243.

Davis PL \& Chace WGJ (1969) Determination of alcohol in citrus juice by gas chromatographic analysis of headspace. HortScience, 4:117-119.

Edagi FK, Chiou DG, Terra FAM, Sestari I \& Kluge RA (2009a) Remoção da adstringência de caquis 'Giombo' com subdosagens de etanol. Ciência Rural, 39:2022-2028

Edagi FK, Sestari I, Terra FAM, Chiou DG, Kluge RA \& Antoniolli LR (2009b) Effect of ripening stage on adstringency removal of 'Rama Forte' persimmon. Acta Horticulturae, 833:269-274.

Ferreira DF (2000) Sistema de análises de variância para dados balanceados. Lavras, UFLA. (pacote computacional).

Handique JG \& Baruah JB (2002) Polyphenolic compounds: an overview. Reactive and Functional Polymers, 52:163-188

Haslam E (1996) Natural Polyphenols (Vegetable Tannins) as Drugs: Possible Modes of Action. Journal of Natural Products, 59:205-215.

FAOSTAT - Food and Agriculture Organization of the United Nations (2016) Disponível em: <http://faostat.fao.org>. Acessado em: 09 de Agosto de 2016.

Karnovsky MJA (1965) Formaldehyde-glutaraldehy de fixative of high osmolality for use in electron microscopy. Journal of Cell Biology, 27:137-138.

Monteiro MF, Edagi FK, Silva MM, Sasaki FF, Aguila JS \& Kluge RA (2012) Temperaturas para remoção da adstringência com etanol em caqui 'Giombo'. Revista Iberoamericana de Tecnología Postcosecha, 13:09-13.

Pesis E (2005) The role of the anaerobic metabolites, acetaldehyde and ethanol, in fruit ripening, enhancement of fruit quality and fruit deterioration. Postharvest Biology and Technology, 37:0119.

Ramin AA \& Tabatabaei F (2003) Effect of various maturity stages at harvest on storability of persimmon fruits (Diospyros kaki L.). Journal of Agricultural Science and Technology, 5:113-123.

Sakai WS (1973) Simple method for differential staining of paraffin embedded plant material using toluidine blue. Stain Technology, 48:247-249.

Salvador AP, Arnal L, Besada C, Larrea V, Quiles A \& Perez-Munuera I (2007) Physiological and structural changes during ripening and deastringency treatment of persimmon fruit cv. Rojo Brilhante. Postharvest Biology and Technology, 46:181-188.

Sugiura A \& Tomana T (1983) Relationships of ethanol production by seeds of different types of Japanese persimmons and their tannin content. HortScience, 18:319-321.

Taira S (1995) Astringency in persimmon. In: Linskens HF \& Jackson JF (Eds.) Fruit Analysis. Hannover, Springer. p. 97-110.

Taira S, Itamura H, Abe K \& Watanabe S (1989) Comparison of the characteristics of removal of astringency in two Japanese persimmon cultivars, 'Denkuro' and 'Hiratanenashi'. Journal of Japanese Society for Horticultural Science, 58:319-325.
Taira S, Itamura H, Abe K, Ooi K \& Watanabe S (1990) Effects of harvest maturity on removal of astringency in Japanese persimmon (Diospyros kaki) 'Hiratanenashi' fruits. Journal of the Japanese Society for Horticultural Science, 58:813-818.

Tessmer MA, Kluge RA \& Appezzato-da-Glória B (2014) The accumulation of tannins during the development of 'Giombo' and 'Fuyu' persimmon fruits. Scientia Horticulturae, 172:292299.

Vázquez-Gutiérrez JL, Quiles A, Hernando I \& Pérez-Munuera I (2011) Changes in the microstructure and location of some bioactive compounds in persimmons treated by high hydrostatic pressure. Postharvest Biology and Technology, 61:137-144.

Vitti DCC (2009) Destanização e armazenamento refrigerado de caqui 'Rama Forte' em função da época de colheita. Tese de Doutorado. Escola Superior de Agricultura "Luiz de Queiroz", Piracicaba. $123 \mathrm{p}$.

Yamada M, Taira S, Ohtsuki M, Sato A, Iwanamia H, Yakushiji H, Wang R, Yang Y \& Li G (2002) Varietal differences in the ease of astringency removal by carbon dioxide gás and ethanol vapor treatments among oriental astringent persimmons of japanese and chinese origin. Scientia Horticulturae, 94:63-72.

Rev. Ceres, Viçosa, v. 63, n.5, p. 646-652, set/out, 2016 